\title{
Airborne pollen records response to climatic conditions in arid areas of the Iberian Peninsula
}

\author{
Paloma Cariñanos*, Carmen Galan, Purificación Alcázar, Eugenio Domínguez \\ Department of Plant Biology, University of Córdoba, Campus Universitario de Rabanales, Colonia San José, \\ 4 Ctra. Madrid km 396, E-14071 Cordoba, Spain
}

Accepted 28 November 2003

\begin{abstract}
This study analyses the responses of the different components of flora from a high-mountain area with a sub-desert climate to changeable meteorological conditions that may affect their normal development. Local airborne pollen levels are used as bio-indicators of the vegetation behavior. In order to determine the fluctuations in this status, a set of 6-year pollen data obtained using aerobiological methods was used. The results show that the tree species (Cupressus sp., Olea europaea; Quercus sp. and Platanus hyspanica) react differently to situations of water stress and changeable temperatures than herbaceous species (Urticaceae, Chenopodiaceae, Poaceae species and Artemisia sp.). The flowering of tree species seems to be affected more by conditions in the months prior to flowering, in particular for species flowering in winter-early spring. As important as the amount of rainfall is the distribution of rainfall throughout the year, since this ensures permanent water availability. Herbaceous species present the most immediate response to weather conditions and if rainfall occurs during their principal pollination period, this period lasts longer. Sometimes, under favorable conditions, non-seasonal flowering may occur.
\end{abstract}

(C) 2003 Elsevier B.V. All rights reserved.

Keywords: Airborne pollen; Arid areas; Water stress; Bio-climatic conditions; Plants adaptation; Mediterranean vegetation

\section{Introduction}

Anemophilous plants produce high amounts of pollen due to the use of wind as vector of pollination reduce the efficiency (Faegri and Van der Pijl, 1979). However, the normal development of flowering in plant species is influenced by the bio-climatic conditions in which this flowering occur. If the conditions are adverse, the plant species design phenological and physiological strategies to survive under new and

\footnotetext{
* Corresponding author. Tel.: +34-957-218719; fax: +34-957-218598.

E-mail address: bv1botan@uco.es (P. Cariñanos).
}

changing conditions (Montenegro, 1987; Rodá et al., 1999), and pollen production may be significantly reduced.

Among the most restrictive factors affecting normal development, water stress caused by irregular rainfall distribution has been cited (Hensen, 1999). Although some species are able to adjust their vegetative and reproductive cycles to availability of water (Raven et al., 1992; Izco et al., 1997), most of them react negatively, keeping the reproductive functions in the minimum compatible with life.

Similarly, extreme temperatures are also cause of responses deviated from the optimum on plant species. Cold stress has been reported as a factor affecting 
microsporogenesis, and pollen production in consequence, both in cultivated species (Satake and Hayase, 1974; Koike et al., 1997) and in those growing in a natural environment (Neilson and Wullstein, 1980; Cannel and Smith, 1984; García-Mozo et al., 2001).

Another environmental adversity affecting normal growing may be the high mountain location, since differences in pollination with decreasing concentrations have been observed at heights above $1000 \mathrm{~m}$ (Frenguelli and Bricchi, 1998; Gehrig and Peeters, 2000).

A combination of the three factors before mentioned: waters-stress, extreme temperatures and high mountain location may start a variety of responses in the vegetation of an area in which these circumstances converge. The airborne pollen records may be used as indicators to know these responses, taking into consideration that once the pollen grains are emitted from the plants into the air, they are likewise subject to the meteorological conditions of the surrounding atmosphere.

Our study is focused on the analyses of the fluctuations observed in airborne pollen records from a high-mountainous sub-desert area located in the southeast part of the Iberian Peninsula as a consequence of the changeable, and on occasions restrictive, meteorological conditions.

\section{Materials and methods}

\subsection{Area description}

The study has been carried out in the locality of Chirivel $\left(37^{\circ} 30^{\prime} \mathrm{N}, 2^{\circ} 11^{\prime} \mathrm{W}\right)$ in the province of Almeria in the southeast of the Iberian Peninsula. This locality, which falls within the limits of the "Sierra de Maria" Natural Park, at a height of $1141 \mathrm{~m}$ a.s.l., presents climatic characteristics typical from a sub-desert region. In terms of annual rainfall, the local climate is defined as arid or semi-arid, according to the Index of Martonne, Lang, Dantin \& Revenga, with a ratio of precipitation/temperature $<2(P / T<2)$ for more than 9 months each year (Allue Andrade, 1990). During the 6 years of study (1995-2000), total rainfall never exceeded $400 \mathrm{~mm}$, and on some occasions this was as low as $220 \mathrm{~mm}$ (1995). Torrential rains are common, with more than $100 \mathrm{~mm}$ of rainfall being recorded in less than $24 \mathrm{~h}$. Most of the rain is lost in surface runoff, forming water avalanches that normally run through dry beds known as "ramblas". Annual average temperature oscillates in the range of $12.5-13.0^{\circ} \mathrm{C}$, coming from strong oscillations between winter and summer temperatures.

Flora in the surrounding area includes both natural plant species and introduced species, consisting in both ornamentals and crops. Typical natural plant species include the well-preserved pine forest on the shady slopes and the holm-oak forest cleared for cattle feeding. Shrubs and grasses are typical of Mediterranean "maquis" (Blanco et al., 1997) and of mountainous scrub vegetation. Species from Chenopodiaceae, Lamiaceae, Leguminosae and Compositae (mainly Artemisia) predominate. It is also worth mentioning the vegetation in the "ramblas", consisting mainly in nitrophylous species resistant to extreme aridity and high salinity. Tamarix is the most common species, sharing its habitat with Chenopodiaceae, grasses, Cyperaceae and Juncaceae (Blanco et al., 1997). Cupressus, Platanus and Populus are the most frequent ornamental tree species, not only in the village but also in the reforestation area, particularly since the completion of construction work on the A-92 highway. The most important crop are is given over to sweet almond trees (Prunus amygdalus subsp. dulcis). Cereal crops alternate between rainfed and irrigated, according to water availability.

\subsection{Techniques}

Air samples containing pollen were collected from the atmosphere of Chirivel using a suction volumetric Hirst-type sampler Burkard spore-trap (Burkard Manufacturing Co., Hertfordshire, UK), placed at the Town Hall at a height of $15 \mathrm{~m}$ a.g.l., as recommended in aerobiological studies (Domínguez et al., 1992). This device worked uninterruptedly from April 1995 to December 2000. Daily samples 00:00-23:59 h obtained were analyzed using optical microscopy $40 \times$ magnification and results showed the pollen spectrum and concentrations expressed in pollen grains $/ \mathrm{m}^{3}$ of air/day. The principal pollination period (PPP) from the main contributive taxa was defined using the methodology proposed by Nilsson and Person (1981), and was established as the period of the year that accounts for $98 \%$ of the total annual count. 


\subsection{Meteorological data}

Meteorological data were supplied by the Territorial Meteorological Centre of Western Andalusia, the National Institute of Meteorology, from an automatic station placed in the village. Data included daily average temperatures and daily total rainfall with an indication of rain or snow. Other phenomena such as frost or wind gusts with speeds of over $50 \mathrm{~km} / \mathrm{h}$ are also indicated. Non-parametric statistical correlation analyses (Spearman's test) were carried out between the meteorological parameters (daily rainfall and daily average temperatures) and pollen data (daily average of pollen grains $/ \mathrm{m}^{3}$ of air) belonging to the eight most common pollen types, in order to determine the reactions of each group under different conditions.

\section{Results}

Fig. 1 shows the characterization of the pollen spectrum measured in the air above Chirivel during the study period. The most representative pollen taxa in the area, i.e. the ones with yearly concentrations above $5 \%$ over the total spectrum and present in air samples during the 6-year study period, are represented graphically. Other taxa were collected in smaller, but also frequent, quantities and other taxa were only detected under specific conditions. The number of pollen types measured ranged from 24 in 1995 to 34 in the final years of the study, due to a degree of recovery after the severe drought suffered in the Iberian Peninsula between 1992 and 1994. In all cases, there were more pollen types from tree species than from herbaceous species. Pollen concentration patterns are shown in Fig. 2, with an upward trend from 1995 to 1999, interrupted only in 2000.

Table 1 shows the characteristics of the 8 most significant airborne pollen types above Chirivel in terms of pollen quantity. Taking into account the chronological appearance of the airborne pollen types, Cupressus, Artemisia and Urticaceae were the pollen types detected first during winter months. Cupressus can be considered a pollen type with a regular behavior, since there was a difference of only 20 days between the year with longest and shortest PPP (excluding 1995). Artemisia stands out for the occurrence of two flowering periods during the year due to the successive flowering of the respective species: A. campestris from June to September and A. barrelieri and A. herba-alba from the end of summer to mid February. Urticaceae pollen was detected in the atmosphere during almost the whole year since this family comprises several species flowering in different seasons. From the palynological standpoint, two groups were distinguished: the Urtica dioica group, including triporate pollen grain species; and the U. membranaceae group, which includes polipantoporate pollen grain species. In the area, $95 \%$ of pollen grains detected in the samples corresponded to the $U$. dioica group (Sagredo, 1987). Urtica species are ruderal weeds common in nitrified locations, such as roadsides and cultivated areas. Platanus is the type with the highest pollen index (PI), that is, the highest total annual counts, with respect to tree species, while Poaceae pollen is the most abundant herbaceous type. Platanus also presented the shortest Principal Pollination period PPP, which was as short as 28 days in 1998. In contrast, Chenopodiaceae pollen can be found in the atmosphere for more than 7 months a year, peaking in May, August or September. Poaceae and Olea lead the group of typical spring flowering species, which normally peak in May or during the first fortnight of June.

Fig. 3 shows the meteorological conditions in the different years considered in this study. Only the rainfall recorded in $1997(400 \mathrm{~mm})$ was close to the average rainfall index for the area according to a 25 -year set of data. The total annual rainfall indices in the other years were considerably lower, particularly in 1995 and 1998 with 220 and $240.6 \mathrm{~mm}$, respectively. More important was the fairly irregular distribution of rainfall over the years studied. In 1995 and 2000, more than $50 \%$ of total rainfall was concentrated in early autumn. Torrential rainfall (more than $100 \mathrm{~mm}$ ) was recorded in only $24 \mathrm{~h}$. In the other years, rainfall was distributed in winter, spring and autumn; 1996 and 1997 were the years with the largest number of rainy months. However, average yearly temperatures were frequently above $12.7^{\circ} \mathrm{C}$ as the mean for the area. 1998 was the coldest year, with an average yearly temperature of $12.06^{\circ} \mathrm{C}$, whereas in 1999 the average yearly average temperature was almost $1{ }^{\circ} \mathrm{C}$ above the mean. Although average monthly temperatures did not fall below $0{ }^{\circ} \mathrm{C}$ in any month, frosts were relatively frequent in winter and early spring, with an average 25 days of frost per year. 

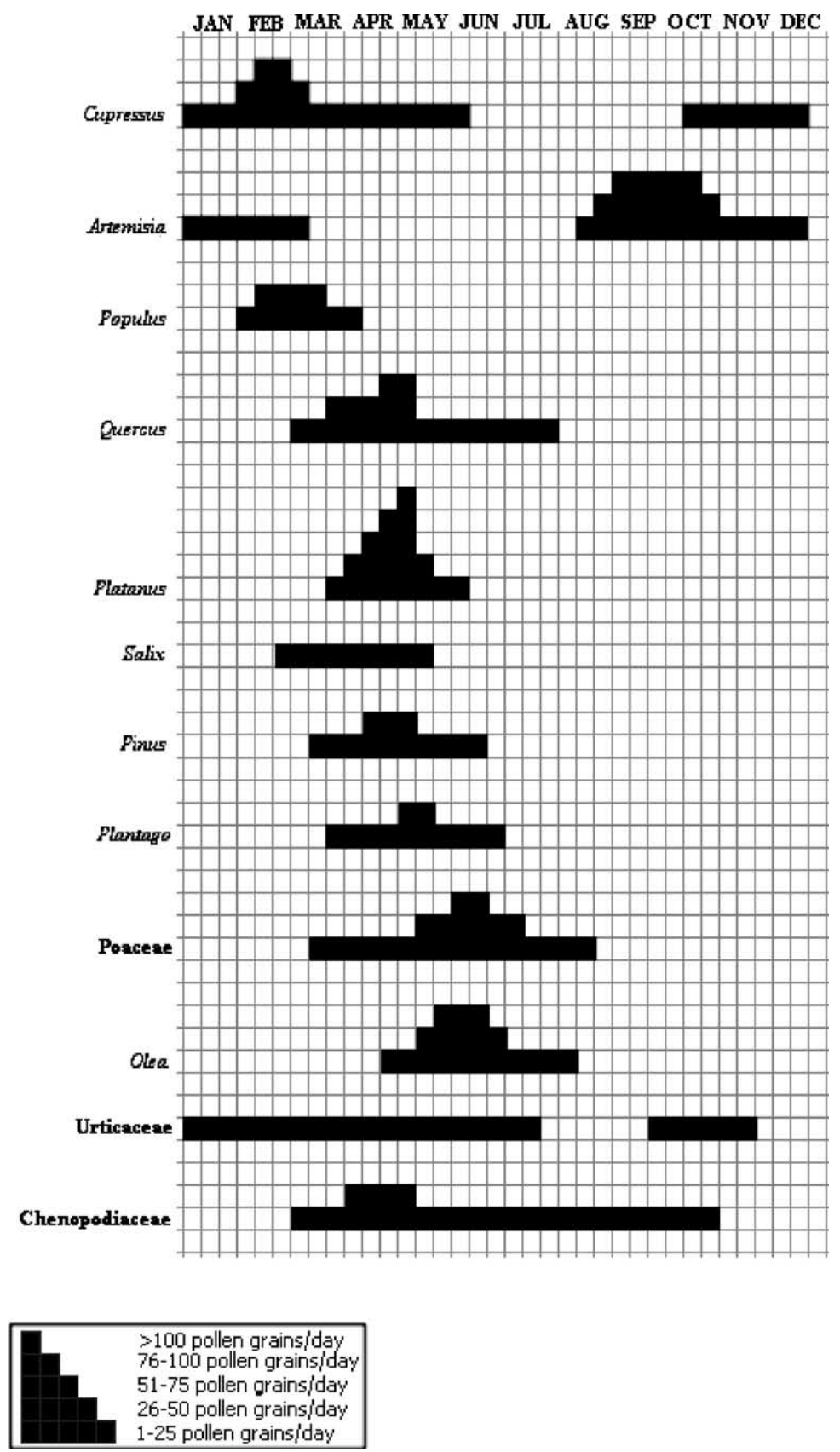

Fig. 1. Characterization of the airborne pollen spectrum of the atmosphere of Chirivel 1995-2000. Each column correspond to 10-day average values. Less frequent taxa (1-5\% over the total): Alnus, Apiaceae, Brassicaceae, Compositae, Cyperaceae, Fraxinus, Mercuarialis, Morus, Myrtaceae, Rumex, Sambucus, Ulmus. Sporadic taxa (less than 1\% over the total): Betula, Cannabis, Castanea, Casuarina, Corylus, Ericaceae, Juglans, Ligustrum, Palmae, Rosaceae. 


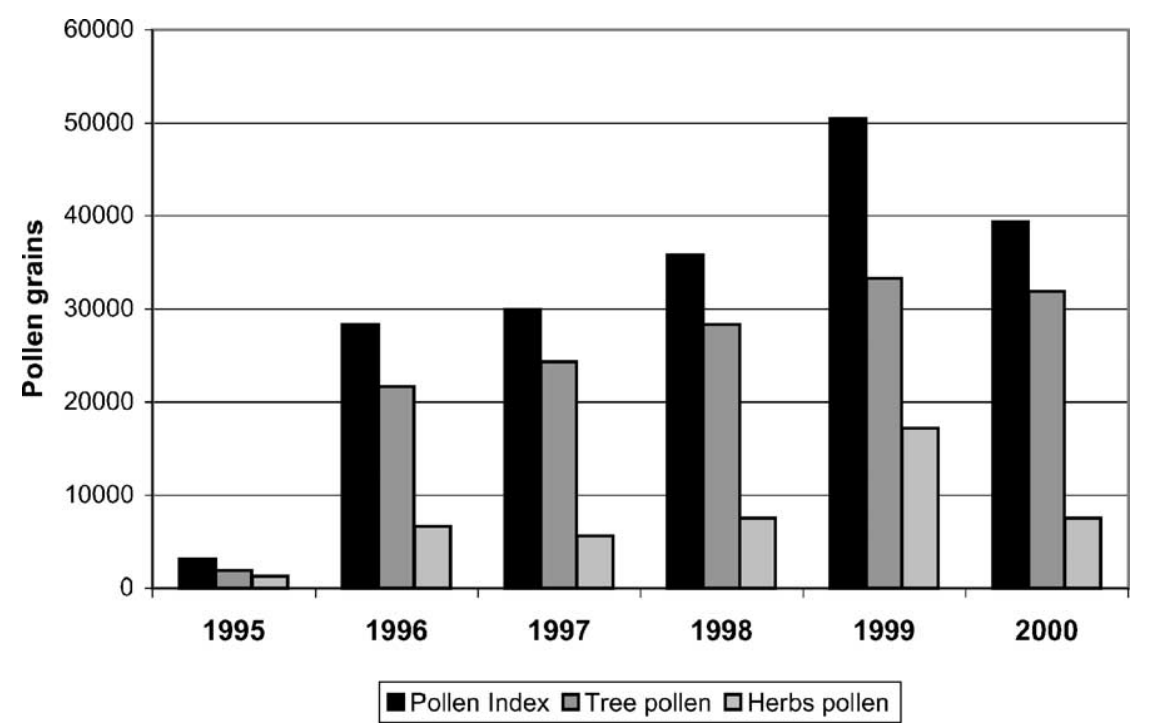

Fig. 2. Total pollen index, total tree pollen and total herbs pollen in Chirivel during the period 1995-2000.

Statistical correlation analysis was carried out between the meteorological parameters (total daily amount of rainfall and daily average temperatures) and the daily pollen concentrations in pollen grains $/ \mathrm{m} 3$ of air of the most important types (Table 2), revealing a very significant relationship between temperatures and pollen concentrations, in particular with Cupressus, Chenopodiaceae and Poaceae. Artemisia was the pollen type least affected by the meteorological conditions and it did not show correlation with temperature or rainfall. Correlation with rainfall was mainly negative, due to the decrease in pollen concentrations prompted by rainfall and also to its irregular distribution in the area, typical of semi-arid areas.

\section{Discussion}

The atmosphere above Chirivel includes almost 34 different pollen types representative of the surrounding flora. Twenty of these can be considered as regulars, while the rest are only found under specific conditions such as sufficient rainfall, long-distance transport or re-suspension by wind gusts. This variety of pollen types is fairly similar to the spectrum recorded in the city of Almeria (Sabariego et al., 1998, 1999), but is much less varied than the 60 types identified in the atmosphere of the region of Murcia (Munuera et al., 2001), although the three areas are included in the same bio-geographical province of Murcia-Almeria. Differences may have been due to the high presence of ornamentals in the city of Murcia and also to the strong fluctuations in the rainfall regime between villages located on both sides of the Mountains and the Föhn effect. Water stress is more severe in Chirivel because of its sunny location.

The response to meteorological conditions was different depending on the arboreal or herbaceous character of the species. In general, the first 2 years of the period studied-1995 and 1996-were marked by a severe drought, which affected normal species development. In 1997, vegetation started a general recovery favored by a rainfall index of $400 \mathrm{~mm}$. Thereafter, each species behaved differently depending on the conditions prior to and during their respective flowering periods. Cupressus is one of the main pollen types and can be detected in the atmosphere in winter months. However, the presence of different species with successive flowering may mean that pollen grains of this type are detected in the atmosphere for longer periods (Hidalgo et al., 1999). As reported previously, temperature seems to be the parameter that has the greatest effect on the presence of Cupressaceae pollen in the atmosphere. Galán et al. (1998a) and Galán et al. (1998b) reported that on a set 
Table 1

Characteristics of the eight most important pollen types in the atmosphere of Chirivel during 1995-2000

\begin{tabular}{|c|c|c|c|c|c|c|}
\hline Pollen type & Year & Pollen index & PPP & Range & Peak & Date of peak \\
\hline \multirow[t]{6}{*}{$\overline{\text { Cupressus }}$} & $1995^{\mathrm{a}}$ & & & & & \\
\hline & 1996 & 2426 & $7 / 1-28 / 4$ & 112 & 184 & $25 / 4$ \\
\hline & 1997 & 2148 & $1 / 1-5 / 5$ & 125 & 215 & $1 / 2$ \\
\hline & 1998 & 2634 & $15 / 1-30 / 4$ & 105 & 175 & $18 / 3$ \\
\hline & 1999 & 3365 & $18 / 1-21 / 5$ & 123 & 489 & $16 / 3$ \\
\hline & 2000 & 2548 & $20 / 1-8 / 5$ & 108 & 276 & $20 / 2$ \\
\hline \multirow[t]{6}{*}{ Platanus } & $1995^{\mathrm{a}}$ & & & & & \\
\hline & 1996 & 12866 & $7 / 4-10 / 5$ & 33 & 2729 & $15 / 4$ \\
\hline & 1997 & 7537 & $11 / 3-9 / 4$ & 29 & 823 & $27 / 3$ \\
\hline & 1998 & 10526 & $10 / 3-25 / 4$ & 46 & 1869 & $10 / 4$ \\
\hline & 1999 & 11175 & $25 / 3-12 / 5$ & 48 & 2338 & $11 / 4$ \\
\hline & 2000 & 16463 & $3 / 3-22 / 5$ & 80 & 2814 & $18 / 3$ \\
\hline \multirow[t]{6}{*}{ Quercus } & $1995^{b}$ & 802 & $22 / 4-28 / 6$ & 67 & 71 & $25 / 4$ \\
\hline & 1996 & 1935 & $29 / 3-11 / 7$ & 104 & 174 & $28 / 5$ \\
\hline & 1997 & 4009 & $12 / 3-9 / 7$ & 89 & 495 & $17 / 3$ \\
\hline & 1998 & 4028 & $17 / 4-28 / 6$ & 72 & 421 & $30 / 4$ \\
\hline & 1999 & 6140 & $19 / 3-1 / 7$ & 104 & 451 & $23 / 4$ \\
\hline & 2000 & 2401 & $23 / 3-24 / 7$ & 123 & 375 & $28 / 3$ \\
\hline \multirow[t]{6}{*}{ Olea } & 1995 & 810 & $22 / 4-28 / 6$ & 67 & 52 & $10 / 5$ \\
\hline & 1996 & 2806 & $20 / 4-4 / 7$ & 75 & 312 & $26 / 5$ \\
\hline & 1997 & 6762 & $8 / 4-25 / 6$ & 78 & 854 & $5 / 5$ \\
\hline & 1998 & 7797 & $3 / 4-2 / 7$ & 89 & 978 & $2 / 6$ \\
\hline & 1999 & 13282 & $26 / 3-6 / 7$ & 102 & 1937 & $16 / 5$ \\
\hline & 2000 & 6072 & $11 / 4-25 / 7$ & 105 & 1172 & $19 / 5$ \\
\hline \multirow[t]{6}{*}{ Poaceae } & $1995^{b}$ & 185 & $29 / 4-24 / 6$ & 56 & 10 & $3 / 5$ \\
\hline & 1996 & 1735 & $16 / 3-9 / 8$ & 146 & 134 & $2 / 6$ \\
\hline & 1997 & 1318 & $11 / 3-4 / 8$ & 146 & 45 & $18 / 5$ \\
\hline & 1998 & 3786 & $2 / 4-15 / 8$ & 133 & 227 & $14 / 6$ \\
\hline & 1999 & 5581 & $26 / 3-19 / 8$ & 146 & 52 & $22 / 5$ \\
\hline & 2000 & 2563 & $17 / 3-11 / 7$ & 116 & 545 & $29 / 5$ \\
\hline \multirow[t]{6}{*}{ Urticaceae } & $1995^{\mathrm{b}}$ & 171 & $26 / 4-31 / 7$ & 96 & 5 & $10 / 6$ \\
\hline & 1996 & 1035 & $11 / 2-7 / 8$ & 177 & 46 & $24 / 3$ \\
\hline & 1997 & 966 & $4 / 2-25 / 7$ & 173 & 42 & $4 / 3$ \\
\hline & 1998 & 1546 & $14 / 1-17 / 8$ & 215 & 27 & $18 / 2$ \\
\hline & 1999 & 1628 & $17 / 2-6 / 9$ & 201 & 49 & $5 / 4$ \\
\hline & 2000 & 1072 & $24 / 1-26 / 8$ & 215 & 20 & $27 / 2$ \\
\hline \multirow[t]{8}{*}{ Artemisia } & 1995 & 199 & $17 / 8-17 / 12$ & 112 & 17 & $12 / 12$ \\
\hline & 1996 & 1714 & $4 / 8-31 / 12$ & 149 & 172 & $26 / 10$ \\
\hline & 1997 & 1556 & $1 / 1-10 / 2$ & 41 & & \\
\hline & 1997 bis. & & $6 / 8-26 / 2$ & 204 & 67 & $27 / 10$ \\
\hline & 1998 & 1630 & $27 / 7-13 / 3$ & 229 & 112 & $2 / 10$ \\
\hline & 1999 & 1337 & $7 / 5-22 / 6$ & 46 & & \\
\hline & 2000 & 1146 & $16 / 8-6 / 3$ & 203 & 73 & $29 / 10$ \\
\hline & 2000 bis. & & $14 / 8-31 / 12$ & 139 & 88 & $29 / 8$ \\
\hline \multirow[t]{6}{*}{ Chenopodiaceae } & 1995 & 332 & $28 / 4-5 / 11$ & 191 & 17 & $3 / 5$ \\
\hline & 1996 & 916 & $8 / 4-24 / 10$ & 199 & 22 & $22 / 5$ \\
\hline & 1997 & 986 & $27 / 3-29 / 10$ & 216 & 31 & $24 / 8$ \\
\hline & 1998 & 1382 & $1 / 4-4 / 11$ & 218 & 39 & $15 / 9$ \\
\hline & 1999 & 1748 & $17 / 3-18 / 10$ & 215 & 45 & $10 / 9$ \\
\hline & 2000 & 1480 & $24 / 2-24 / 10$ & 243 & 54 & $25 / 8$ \\
\hline
\end{tabular}

a Taxa affected by the starting date of sampling 22 April.

b Taxa partially affected by the starting date of sampling 22 April. 
1995

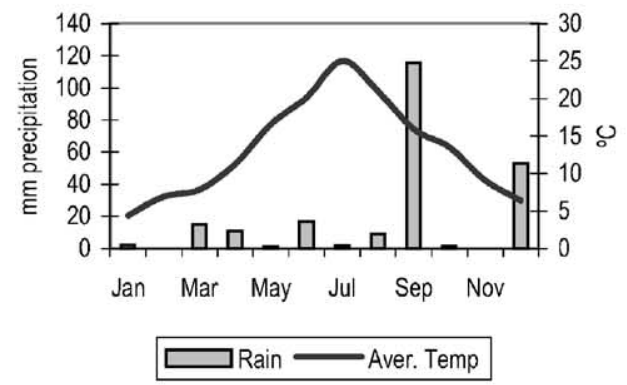

Total rainfall: $220 \mathrm{~mm}$

Aver. $T^{\text {a. }} 13.3^{\circ} \mathrm{C}$

1997

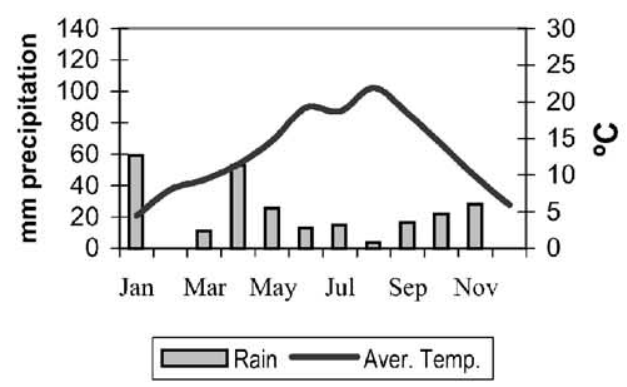

Total rainfall: $400 \mathrm{~mm}$

Aver. $T^{\mathrm{a}}: 13.5^{\circ} \mathrm{C}$

1999

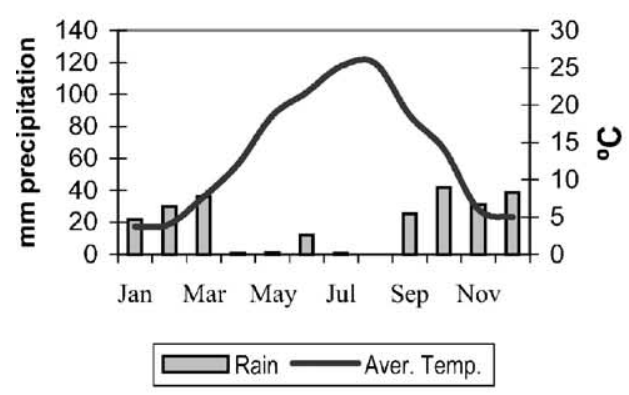

Total rainfall: $240.6 \mathrm{~mm}$

Aver. $\mathrm{T}^{\mathrm{a}}$ : $13.54^{\circ} \mathrm{C}$
1996

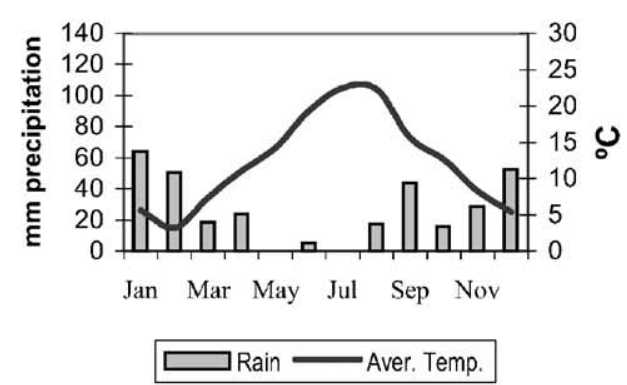

Total rainfall: $310 \mathrm{~mm}$

Aver. Ta. $12.43^{\circ} \mathrm{C}$

1998

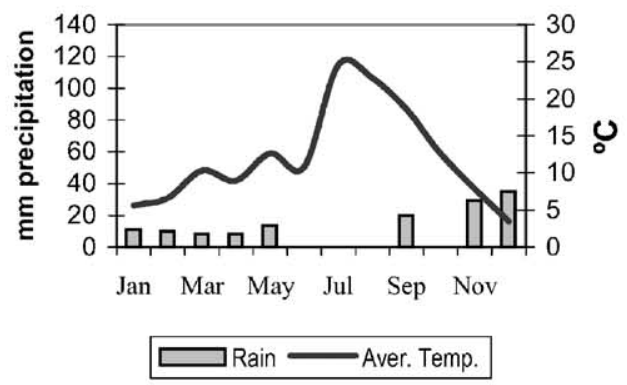

Total rainfall: $258.6 \mathrm{~mm}$

Aver. T ${ }^{\text {a }} 12.06^{\circ} \mathrm{C}$

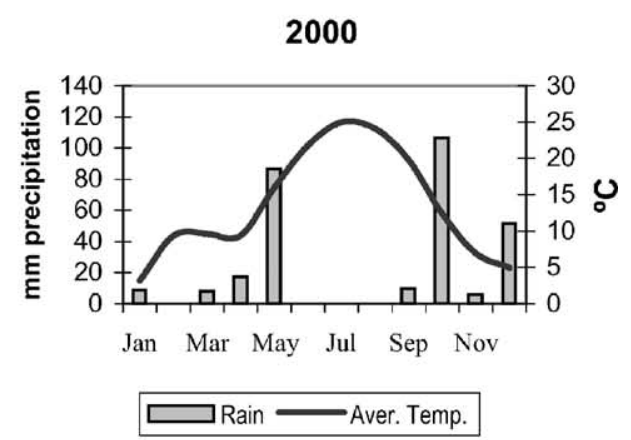

Total rainfall: $273.9 \mathrm{~mm}$

Aver. $\mathrm{T}^{\mathrm{a}}$ : $13.43^{\circ} \mathrm{C}$

Fig. 3. Monthly average temperature and monthly total precipitation in Chirivel during the period 1995-2000.

of thirteen consecutive years, Cupressaceae daily data were linked to minimum temperatures, being this parameter the first entering in the regression formulae. In Chirivel, the relative occurrence of frosts during the Cupressus flowering period prompt a decrease in the average temperatures, resulting in conditions more suitable for airborne pollen presence. This fact would explain the strong negative correlation between 
Table 2

Spearman's correlation between the daily concentrations of the eight most representative pollen taxa in the atmosphere of Chirivel and daily values of average temperature and precipitation during the 6-year period of study

\begin{tabular}{|c|c|c|c|c|c|c|c|c|c|c|c|c|}
\hline & \multicolumn{2}{|l|}{1995} & \multicolumn{2}{|l|}{1996} & \multicolumn{2}{|l|}{1997} & \multicolumn{2}{|l|}{1998} & \multicolumn{2}{|l|}{1999} & \multicolumn{2}{|l|}{2000} \\
\hline & Temperature & Precipitation & Temperature & Precipitation & Temperature & Precipitation & Temperature & Precipitation & Temperature & Precipitation & Temperature & Precipitation \\
\hline Cupressus & $-0.421^{*}$ & -0.105 & $-0.441^{*}$ & -0.205 & $-0.645^{*}$ & 0.001 & $-0.336^{*}$ & 0.005 & $-0.389^{*}$ & 0.102 & $-0.520^{*}$ & -0.011 \\
\hline Platanus & 0.014 & -0.169 & $0.295^{* *}$ & -0.130 & -0.170 & 0.028 & 0.336 & -0.073 & $0.295^{* *}$ & -0.165 & -0.124 & -0.068 \\
\hline Quercus & 0.196 & -0.216 & $0.384^{*}$ & -0.172 & 0.179 & -0.038 & $0.532^{* *}$ & -0.126 & $0.622^{*}$ & -0.172 & $0.448^{*}$ & -0.077 \\
\hline Olea & 0.068 & -0.201 & $0.659^{*}$ & 0.038 & 0.185 & 0.065 & $0.648^{*}$ & -0.037 & $0.692^{*}$ & $-0.284^{* *}$ & $0.740^{*}$ & -0.048 \\
\hline Poaceae & 0.000 & -0.052 & $0.459^{*}$ & -0.150 & $0.454^{* *}$ & -0.249 & $0.436^{*}$ & -0.273 & $0.647^{*}$ & -0.181 & $0.580^{* *}$ & -0.142 \\
\hline Urticaceae & -0.050 & 0.135 & -0.019 & $-0.350^{* *}$ & 0.158 & -0.183 & 0.037 & -0.241 & $0.347^{* *}$ & -0.055 & 0.075 & -0.142 \\
\hline Chenopodiaceae & $0.501^{*}$ & -0.144 & $0.861^{*}$ & 0.021 & $0.806^{*}$ & -0.123 & $0.744^{*}$ & -0.124 & $0.832^{*}$ & -0.248 & $0.893^{*}$ & -0.124 \\
\hline Artemisia & -0.097 & 0.179 & -0.254 & 0.187 & -0.112 & -0.008 & -0.135 & -0.088 & 0.030 & 0.037 & $-0.275^{* *}$ & 0.96 \\
\hline
\end{tabular}

Correlation is significant at the 0.01 leve

** Correlation is significant at the 0.05 level. 
temperatures and Cupressus shown in Table 2. The lower the temperature, the higher the pollen presence.

Platanus is a typical urban species forming shadow lines along the main streets of the village. Plane trees usually flower between mid-March and April and flowering intensity is affected most by the conditions in the months prior to flowering than by conditions during flowering. The highest plane tree pollen levels were recorded in the years with sufficient rainfall in the winter-early spring months (November, December and January), together with moderate temperatures that were rarely below $0{ }^{\circ} \mathrm{C}$. In 1996 and 1999, these requirements were fulfilled. In the first quarter of the corresponding years, rainfall was not very abundant but regularly distributed, thus ensuring permanent water reserves. Moreover, the warm temperatures ensured uninterrupted water absorption, a situation that frequently occurs in high mountain areas when temperatures drop below $0{ }^{\circ} \mathrm{C}$ (Izco et al., 1997), and, as in the case of other species in Mediterranean climates, the required number of hours of heat to break dormancy (Galán et al., 2001; Frenguelli and Bricchi, 1998) was accumulated earlier. This fact was confirmed by the statistics, with significant and positive correlation with temperatures and Platanus pollen concentrations. The high Platanus PI recorded in 2000 was prompted by the long flowering period, which lasted 80 days and was favored by the almost total absence of rainfall during the pollen season.

Quercus pollen responded differently to meteorological conditions. Oak trees are well-adapted to Mediterranean climates, forming typical forests. Bark thickening and coriaceous recovering on their leaves fostered growth even in areas with an index $P / T<$ 2 during several months a year (Rivas Martínez, 1987). Five Quercus species grow in the area: $Q$. ilex subsp. ilex, $Q$. ilex subsp. ballota, $Q$. coccifera, $Q$. suber and $Q$, faginea. Their flowering periods overlap and last from mid March to early June. As in the case of other species such as birch and olive tree, Quercus pollen production presents a biennial cyclic pattern (Emberlin et al., 1990; García-Mozo et al., 1999). The behavior of Quercus pollen over the 6-year set of data was rather irregular. Again, the rainfall regime influenced the pollen season characteristics. Once the drought ceased, Quercus pollen started to recover and a similar PI was recorded in 1997, 1998 and 2000; the peak concentrations were reached earlier or later according to the rainfall regime. Year 1999 must be treated differently, since this was the year in which the maximum Quercus PI was recorded. Total annual rainfall was only $240.6 \mathrm{~mm}$. However, distribution through the year was rather regular. Non-persistent rainfall fostered water filtration through the soil, recovery of aquifers and higher availability of water for plant species. Temperature has been also mentioned as an important parameter influencing Quercus pollination. García-Mozo et al. (2002) established the base temperature from which Quercus species start to accumulate heat. This accumulation threshold is related to the mean air temperature of the corresponding sites. For areas such as Chirivel, with an annual mean air temperature of $12^{\circ} \mathrm{C}$, the base temperature has been established at $4-5^{\circ} \mathrm{C}$, and this can be translated as an average of $400^{\circ} \mathrm{C}$ accumulated as from 1 January. Warm temperatures during the winter of 1999, prompted by the position of a high-pressure area in the south of the Iberia Peninsula, meant that this threshold was reached earlier, at the beginning of April, coinciding with a period of scarce rainfall.

A similar situation was observed in the case of Olea, the maximum pollen levels for which were also recorded in 1999. In this case, the source of emission was detected $20 \mathrm{~km}$ west of the sampling point in "Vega" (irrigated plain) of Velez Rubio. In addition to temperature and rainfall, wind also played an important role and was involved in the transport of pollen grains from its source of origin to other areas in its trajectory.

Herbaceous species, which included a large number of species with different requirements and reactions to meteorological conditions, behaved differently to arboreals. In terms of those with anemophilous pollination, three main categories can be established: cosmopolitan species with long flowering periods (i.e. Poaceae, Urticaceae species); species belonging to cosmopolitan families, but adapted to arid conditions (i.e. Artemisia, Chenopodiaceae and Amaranthaceae species) and sporadic species appearing under specific conditions (i.e. Cannabis).

The first group of plants includes the main cosmopolitan species in the Iberian Peninsula, but also some species endemic to the south-eastern area: Festuca pseudeskia, F. capillifolia, Elymus pungens, Aegilotricum $\times$ triticoides and Eragrostis papposa (Sagredo, 1987). Grass pollen was detected in the 
atmosphere throughout the year, peaking by May or June. Flowering was more intense if rainfall occurred in the 4-week period prior to flowering. This occurred in 1996, 1998 and 1999, when maximum concentrations were recorded. Temperatures also played an important role. In 1999, the average temperature in May was $18.64^{\circ} \mathrm{C}$, almost $4{ }^{\circ} \mathrm{C}$ higher than in the same month in 1996; and $6^{\circ} \mathrm{C}$ higher than in May 1998. This fact is confirmed by statistics, with a high positive significant correlation between Poaceae pollen and temperatures. Rainfall in June prolonged flowering and as a result grass counts in 1999 were three times higher than those of the rest of the set.

Urticaceae is another cosmopolitan family. The PPP of Urticaceae may last from February to June, longer than described for other areas in Andalusia (Galán et al., 2000; González Minero et al., 1997; Trigo et al., 1996). Although no correlation was detected with temperature and rainfall, maximum nettle pollen concentrations were recorded in years with a certain amount of rainfall prior to and during flowering (1998 and 1999). In 1997, a peak of 106 grains $/ \mathrm{m}^{3}$ was recorded in July, just after a period of two rainy weeks, with a total rainfall of $15 \mathrm{~mm}$. Their presence was also conditioned by crop tillage after harvesting.

Pollen from Chenopodiaceae-Amaranthaceae species form a stenopalynous group due to the morphological similarities of their pollen grains. Both, the pollen records and the PPP were rather homogeneous through the 6 years of study. ChenopodiaceaeAmaranthaceae species are highly adapted to arid conditions and only show stress during prolonged periods of drought. In contrast, high temperatures seem to favor flowering, since the maximum levels were recorded in the years in which there were no sharp drops in temperature between the end of summer and the beginning of autumn (i.e. $3-4^{\circ} \mathrm{C}$ in 1997-1999).

Artemisia can be considered the most characteristic local herbaceous species (Cariñanos et al., 2000; Munuera, 1999). Of the 20 species of mugwort growing in the Iberian Peninsula (Tullin et al., 1976; García Rollan, 1996), seven only grow in the province of Almeria, where the climate is dry and the land contains limestone, salt and gypsum. As in the case of Chenopodiaceae-Amaranthaceae pollen, mugwort pollen is collected from air samples during a long but discontinuous period throughout the year. Given its herbaceous nature and the location of the trap $15 \mathrm{~m}$ a.g.l., the pollen levels were not as high as could be expected but were indicative of their status. The maximum levels of mugwort pollen were collected in rainy periods. In autumn 1996, a peak of 172 pollen grains was recorded in the interval between two rainy periods in October and November. In 1999, additional flowering took place in May-June just after an infrequent rainy autumn and winter. Torrential rainfall does not favor this or other species, due to the damage caused to the land surface. These rains occurred in September 1995 and October 2000, when more than $100 \mathrm{~mm}$ of rainfall were recorded in only $24 \mathrm{~h}$. After this, the pollen counts failed to recover its normal values.

Cannabis is a sporadic taxa, appearing in years with a prevalence of south-eastern direction winds of north-African origin, although there are also some local growths. Other interesting types include Apiaceae, Fagaceae and Lamiaceae, entomophilous species well-adapted to arid environment, whose presence was only noticeable after episodes of wind gusts, relatively frequent in the areas, but with a high recurrence in 2000. Rather than effect flowering, winds at speeds of more than $60 \mathrm{~km} / \mathrm{h}$ favored re-floating of pollen grains deposited on the ground and leaves.

The above findings show how airborne pollen concentrations may be used as indicators of vegetation response to changeable meteorological conditions in a particular area where water stress, rigorous temperatures and high mountain character affect the normal development of the flora. In general, the flowering of tree species is more affected by the conditions in the months prior to flowering. Thus, very low minimum temperatures may affect both the water availability and the accumulation of the required number of hours of heat to break dormancy. The distribution of rainfall throughout the year is also important, since a regular rainfall regime ensures a recovery of aquifers and permanent water availability. Herbaceous species present the most immediate response to weather conditions. A more intense flowering has been observed in herbaceous species if rainfall occurred in the 2-4-week period prior to flowering. In case of rainfall during their principal pollination period, then this was prolonged. However, torrential rainfall is not favorable for any species to flower due to the damage caused to the land surface. Lastly, high temperatures seem to favor flowering of species adapted to arid conditions, that 
show on the contrary stress during prolonged periods of droughts.

\section{Acknowledgements}

The authors thank the European Union Commission for financial support through Project SPRING (CT26811) and the City Town of Chirivel for collaborative support in the manage of the sampler.

\section{References}

Allue Andrade, J.L., 1990. Atlas Fitoclimático de España. Instituto Nacional de Investigaciones Agraria. Ministerio de Agricultura, Pesca y Alimentación, Madrid.

Blanco, E., Casado, M.A., Costa, M., Escribano, R., Garcia, M., Génova, M., Gómez, F., Moreno, J.C., Morta, C., Regata, P., Sainz, H., 1997. Los bosques Ibéricos. Planeta Editorial, Barcelona.

Cannel, M.G., Smith, R.I., 1984. Spring frost damage on young Picea sitchensis. Predicted dates of budburst and probability of frost damage. Forestry 57, 177-195.

Cariñanos, P., Galán, C., Alcázar, P., Domínguez, E., 2000. Allergenic pollen in the subdesert areas of the Iberian peninsula. J. Invest. Allerg. Clin. Immunol. 10, 242-247.

Domínguez, E., Galán, C., Villamandos, F., Infante, F., 1992. Handling and evaluation of the data from aerobiological sampling. Monografías REA/EAN1, Universidad de Córdoba.

Emberlin, J., Norris-Hill, J., Bryant, R., 1990. A calendar for tree pollen in London. Grana 29, 301-309.

Faegri, K., Van der Pijl, L., 1979. The Principles of Pollination Ecology, third ed. Pergamon Press, Oxford.

Frenguelli, G., Bricchi, E., 1998. The use of pheno-climatic model for forecasting the pollination of some arboreal taxa. Aerobiologia 14, 39-45.

Galán, C., Fuillerat, M.J., Comtois, P., Domínguez, E., 1998a. Bioclimatic factors affecting daily Cupressaceae flowering in Southwest Spain. Int. J. Biometeorol. 41, 95-100.

Galán, C., Fuillerat, M.J., Comtois, P., Domínguez, E., 1998b. A predictive study of Cupressaceae pollen season onset, severity, maximum value and maximum value date. Aerobiologia 14, 195-1999.

Galán, C., Alcázar, P., Cariñanos, P., García-Mozo, H., Domínguez, E., 2000. Meteorological factors affecting daily urticaceae pollen counts in southwest Spain. Int. J. Biometeorol. 43, 191195.

Galán, C., Garcia-Mozo, H., Cariñanos, P., Alcázar, P., Domínguez, E., 2001. The role of the temperature in the onset of the Olea europaea L. pollen season in southwestern Spain. Int. J. Biometeorol. 45, 8-12.

García Rollan, M., 1996. Atlas clasificatorio de la Flora de la España Peninsular y Balear. Ministerio de Agricultura, Pesca y Alimentación, Madrid.
García-Mozo, H., Galán, C., Cariñanos, P., Alcázar, P., Méndez, J., Vendrell, M., Alba, F., Sáenz, C., Fernández, D., Cabezudo, B., Domínguez, E., 1999. Variations in the Quercus sp. Pollen season at selected sites in Spain. Polen 10, 5969.

García-Mozo, H., Hidalgo, P., Galán, C., Gómez-Casero, M.T., Domínguez, E., 2001. Catking frost damage in Mediterranean cork-oat (Quercus suber L.). Israel J. Plant Sci. 49, 4147.

García-Mozo, H., Galán, C., Aira, M.J., Belmonte, J., Díaz de la Guardia, C., Fernández, D., Gutierrez, M., Rodríguez, F.J., Trigo, M.M., Domínguez, E., 2002. Modelling start oak pollen season in different climatic zones in Spain. Agric. For. Meteorol. 110, 247-257.

Gehrig, R., Peeters, A.G., 2000. Pollen distribution at elevation above $1000 \mathrm{~m}$ in Switzerland. Aerobiologia 16, 69-74.

González Minero, F.J., Candau, P., Tomás, C., Morales, J., 1997. Variación anual y estacional del polen de Urticaceae en el aire de Sevilla y su relación con los parámetros meteorológicos. Polen 8, 69-77.

Hensen, I., 1999. Life strategies of semi-desert plants: mechanisms of dispersal and reproduction in the thermomediterranean shrubland community Anabasio-Euzomodendretum bourgaeani. Anales del Jardín Botánico de Madrid 57, 63-79.

Hidalgo, P.J., Galán, C., Domínguez, E., 1999. Pollen production of the genus Cupressus. Grana 38, 296-300.

Izco, J., Barreno, E., Brugués, M., Costa, M., Devesa, J., Fernández F., Gallardo, T., Llimona, X., Salvo, E., Talavera, S., Valdés, B., 1997. Botánica. McGraw-Hill Interamericana, Madrid.

Koike, S., Hayashi, T., Yamaguchi, T., Suzuki, K., 1997. Chilling injury during microsporogenesis in lily. Plant Physiol. 114, 242.

Montenegro, G., 1987. Quantification of Mediterranean plant phenology and grow. In: Tenhunen, J.D., Catarino, F.M., Lange, O.L., Vechel, W.C. (Eds.), Plant Responses to Stress, Functional Analysis in Mediterranean Ecosystems. NATO ASI Series, vol. G15. Springer, Berlin, pp. 469-488.

Munuera, M., 1999. Patrones de variación polínica en la atmósfera de Murcia. Implicaciones alergológicas, prevención y tratamiento. Tesis Doctoral. Universidad de Murcia.

Munuera, M., Carrión, J.S., Navarro, C., Orts, L., Espín, A., Sáez, F., García, J., 2001. Guía de las plantas de polen alergógeno en la Región de Murcia y España, Murcia.

Neilson, R.P., Wullstein, L.H., 1980. Catking freezing and acorn production in gambel oak in Utah. Am. J. Bot. 67, 426-428.

Raven, P.H., Evert, R.F., Eichhorn, S.E., 1992. Biology of Plants. Worth Publishers, Inc., New York.

Rivas Martínez, S., 1987. Memoria del mapa de vegetación en España. ICONA, Madrid.

Rodá, F., Retama, J., Gracia, C.A., Bellot, J., 1999. Ecology of Mediterranean Evergreen Oak Forest. Springer-Verlag, Berlin.

Sabariego, S., Díaz de la Guardia, C., Mota, F.J., 1998. Aerobiología en Andalucía: Estación de Almería. REA5: 19-22.

Sabariego, S., Díaz de la Guardia, C., Alba, F., Mota, F.J., 1999. Aerobiología en Andalucía: Estación de Almería. REA6: $11-14$. 
Sagredo, R., 1987. Flora de Almeria. Almeria, Instituto de Estudios Almerienses.

Satake, T., Hayase, H., 1974. Male sterility caused by cooling treatment at the young microspore stage in rice plants. V. Estimation of pollen developmental stage and the most sensitive stage and the most sensitive stage to coolers. Proc. Crop. Sci. Soc. Jpn. 39, 468-473.
Trigo, M.M., Cabezudo, B., Recio, M., Toro, F.J., 1996. Annual, daily and diurnal variations of Urticaceae airborne pollen in Málaga (Spain). Aerobiologia 12, 85-90.

Tullin, T.G., Heywood, V.H., Burger, N.A., Moore, D.M., Valentina, D.H., Walter, S.M., Webb, D.A., 1976. Flora Europaea. Cambridge University Press, Cambridge. 